\title{
Introduction: The theory of institutional innovation - an overview
}

Institutional innovation has become one of the key concepts of democratic theory (Almeida, 2015; J. Cohen, 1997; Dryzek, 2000, 2006; Elstub et al., 2016; Fischer, 2000; Goodin, 2005, 2008; Habermas, 1994; Geissel and Newton, 2012; Smith, 2009; Spada, 2013). The origins of institutional innovation are rooted in recent changes in contemporary Northern and Southern democracies. On the one hand, in old and consolidated democracies of the North, changes in public policy in areas such as housing, the environment and compensatory policies have generated innovations that have increased the level of citizen participation and produced more effective results (Fischer, 2000; Fung, 2007; Fung and Wright, 2003; Sintomer et al., 2008; Sirianni and Friedland, 2001). At the same time, the idea of experimenting with democratic design has acquired relevance through the proliferation of mini-publics (Fung, 2003; Parkinson, 2006; Parkinson and Manbridge, 2012; Smith, 2009). Mini-publics are small groups 'genuinely deliberative and representative enough to be genuinely democratic' (Goodin and Dryzek, 2006, p. 220). Because of their size mini-publics have become experiments in democracy and in public policy. In certain cases, such as in the British Columbia experiment, mini-publics have discussed changes in electoral rules (Warren and Pearse, 2008). In other cases, such as healthcare in Britain, mini-publics have debated the quality of public policy and proposed innovation (Parkinson, 2006). Thus, experimenting with democracy has become an important political aim in the agenda of old and consolidated democracies.

Alongside institutional innovations in the North, democratization in Southern countries has provided parallel cases of institutional innovation in new democracies, particularly in Latin America (Ackerman, 2007; Annunziata, 2011; Avritzer, 2013; Avritzer and Ramos, 2016; Hevia and Isunza, 2010; Ramos and Faria, 2013; Seele and Peruzzotti, 2010). The Latin American cases, and particularly 
the Brazilian case, have one similarity with and one difference from the Northern cases. The similarity is that they are also strongly concentrated in policy (Cambraia, 2014; Pires, 2011) and connected to social movements in important areas such as healthcare and social assistance (Cunha and Almeida, 2016; Ramos and Faria, 2013). The difference is that they are connected with participatory mechanisms that are institutions in charge of producing decisions that are binding for the political system, which makes them more effective but also more contentious (Avritzer, 2016a).

The spread of institutional innovation in old, well-established democracies in the North, as well as in new democracies in the South, has made innovation a trendy phenomenon. Some experiences, such as participatory budgeting, have become world famous and are practised in all parts of the world (Allegretti, 2014; Sintomer, 2007, 2010). Other experiences, such as mini-publics, are practised from Australia to British Columbia (Warren and Pearse, 2008). Even in the legal system, innovation has been introduced but with highly ambiguous results (Avritzer and Marona, 2017). Thus, the issue of widespread diffusion of innovation is: are there limits to the positive aspects of political and institutional innovations, or are innovations good per se? Because there are good reasons to promote innovation but also to stick with a democratic core of norms without which democracy itself may be endangered, the second question is: how can we learn to separate the positive from the negative elements of institutional innovation?

This book will try to answer these questions by differentiating types of innovation, reasons for introducing innovation and timing of political innovation and innovation diffusion. The first issue is perhaps the most important. The differentiation of types of innovation, a task carried out by only a few scholars (e.g., Hevia and Isunza, 2010), is important to discovering whether innovation serves to strengthen participation, to empower citizenship or to empower specific groups or corporations. I will argue that in many cases innovation can play the role of co-optation and disempowerment. It is also important to have a much broader grasp on diffusion of innovation because in many cases the adoption of innovation is limited to propagandistic effects.

The second issue is areas of innovation. Innovation originated in areas of public policy in both Northern and Southern democracies. In the case of public policies, I will argue that innovation usually 
produces positive results such as greater citizenship engagement or more equitable distribution of public goods (Fischer, 2000, 2009; Pires and Vaz, 2010; Wampler, 2015). In addition, I will argue that innovation in public policy, even when it does not work well, never poses dangers to democracy. These cases should be clearly distinguished from the cases of innovation in judicial institutions, one of the key areas in which innovation took place in Latin America, particularly in Brazil but also in Colombia. This could be much more problematic, because the role of legal corporations in democracy cannot be compared with the role of engaged citizens.

To evaluate these cases and provide a broader approach, I will define political/democratic innovation as the capacity of government to express political will and civil society inputs in several formats. Usually, these inputs are linked to the introduction and/or implementation of public policies, through which civil society and the state interact in order to democratize the state itself.

Thus, one of the issues that the book will approach is the differentiation in innovation. I will argue that there are two types of innovation: political/democratic and administrative/judicial. Most of the literature conflates the two and assumes that administrative innovation can have democratizing effects. I will show in the book that this mistake goes back in history to the New Deal in the United States between 1933 and 1938 that bureaucratized the democratic drives behind progressivism (Pestritto and Atto, 2008, p. 15). Thus, innovation in policy needs to be differentiated into political and administrative. It is this book's argument that innovations in new Latin American democracies also need to be differentiated in their administrative and democratic aspects. Figure 0.1 shows the model of differentiation of innovation that I am proposing.

The differentiation between democratic innovation and administrative/judicial innovation is the main theme of this book. Political and administrative innovations became intertwined in Latin America and differentiation is complicated. I understand political and democratic innovations as those that, through changes in design, give citizens the capacity to participate in policy elaboration and to benefit from the results of policy. I understand judicial/administrative innovation in two different ways: as self-contained changes that strengthen rights-based policies and as top-down changes in policy made through judicial institutions and agencies that strengthen the power of the legal corporation members. They may both broaden 


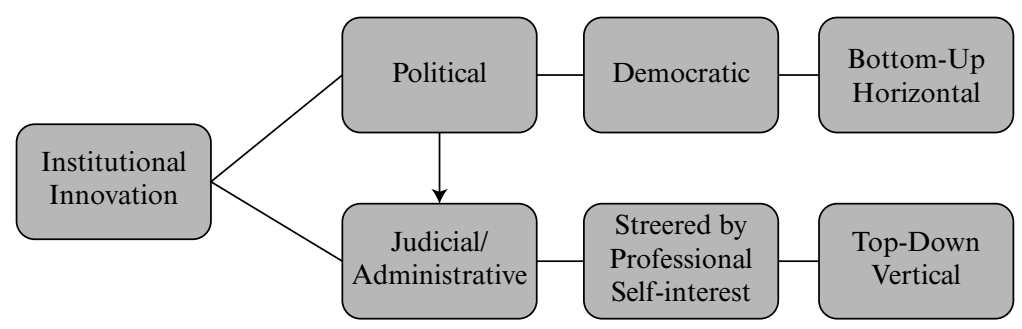

Figure 0.1 Types of institutional innovation

rights but even in those cases, the top-down examples do not favour the democratization of state and society's interfaces.

There has been a sharp increase in both democratic innovations and administrative innovations in Southern democracies, in particular in those located in Latin America. The motive for the concentration of innovation in Latin America is the process of constitution-making that took place in the region after democratization (Avritzer et al., 2017). Constitution-making took place in Brazil (1988), Colombia (1991) and Bolivia (2009), among other countries. In each of these cases, there were important innovations in at least two areas - participation and the organization of the judicial system.

Participation was introduced as an innovation in Brazil in different parts of the 1988 Constitution. Among the important changes introduced is a significant increase in forms of participation, all of them grounded on the idea of broader participation introduced in Article 1. The Bolivian Constitution has similar articles. In fact, before Bolivia created its Constitution, it promulgated (in 1994) the Popular Participation Law - the Ley de Participación Popular (Oxhorn, 2001). Thus, all new constitutions in Latin America created new venues for participation and even the cases in which there has not been the crafting of new constitutions (Mexico and Argentina), participation increased through ordinary laws or international treaties.

A similar innovation was introduced at the level of the organization of the judicial system. Brazil, Colombia and Bolivia introduced new forms of organization, whereas Argentina did not write a new constitution but added a large constitutional amendment in 1994 (Abramovich, 2009) and introduced new practices in the legal system. In Chapter 5, I will discuss the Brazilian and the Colombian cases. In the Brazilian case, the Ministério Público (Public Prosecutor's Office) 
was the most important innovation. The Ministério Público and the idea of the separate autonomy of legal bodies emerged in the writing of the Brazilian 1988 Constitution. Autonomy of legal bodies was practised in Brazil and is now extended to many areas, including the Federal Police. The practice of legal autonomy is creating autonomous judicial bodies above sovereignty and the rule of law, showing that innovations need to be differentiated according to their role in deepening democracy. Colombia is a different case in that there is a much more self-limited role attributed to the Constitutional Court than in Brazil. In the next section I will differentiate these innovations according to their capacity to promote more active citizenship and strengthen democracy or to organize judicial corporative bodies.

\section{DEMOCRATIC INNOVATIONS IN BRAZIL, ARGENTINA AND EUROPE: ORIGINS, EFFECTS AND EXPANSION}

Democratic innovations in Latin America have introduced many new policy experiences in Latin America and most of them have led to the increase in social participation or state and society interfaces, among them participatory budgeting, policy councils, citizenship councils such as the Federal Electoral Institute, (Instituto Federal Electoral IFE), in Mexico and the comités de vigilancia (monitoring committees) in Bolivia. In all cases, we see both success and failure; figuring out what makes an innovation successful is key to the continuing success of innovations.

The most important democratic and participatory innovation that has emerged in democratic Brazil is participatory budgeting. Participatory budgeting is a local practice of public deliberation on budget issues. Introduced in Porto Alegre in 1989, participatory budgeting was expanded to 103 cities in 2003 and to 201 additional cities in 2008 (Avritzer and Wampler, 2008). It is practised in more than 300 Brazilian cities today. Participatory budgeting spread beyond Brazil to other South American cities and was very successful in Argentina in the city of Rosário (Annunziata, 2011, 2013). Participatory budgeting has been adopted in Europe, and we see cases such as Portugal where the main phenomenon is the death of participatory budgeting (Allegretti, 2014). How can we evaluate the different experiences of participatory budgeting? 
Participatory budgeting is characterized by four elements: the first is the delegation of sovereignty by elected mayors to a set of regional and thematic assemblies that operate through universal criteria of participation. Every citizen can participate and vote on budget issues in regional and thematic assemblies. The second characteristic is the combination within the participatory model of different elements of participation that belong to different participatory traditions, such as direct participation and election of councillors at the city level. The third element is the principle of self-regulation. The rules for participation and deliberation are defined by the participants themselves and are adapted or changed every year (B. Santos and Avritzer, 2002). The fourth element is an attempt to invert priorities in the distribution of public goods through a combination of participation and technical decisions about who should have access to public goods.

Participatory budgeting had two main effects in Porto Alegre from 1990 to 2004. The first effect was a sharp democratization of political practices. As I will show in Chapter 3, this democratization involves the following aspects: more participation at the local level, better information on and transparency of state policies, transfer of decision-making from the mayor to the participatory budgeting council, learning negotiation skills by grassroots actors and democratization and decentralization of public goods so that more resources are going to poor rural areas and deprived neighbourhoods.

Theorists of democratic or participatory innovation should pose two questions: (1) What factors account for these results? (2) Can we keep these characteristics in an expanded design? I will try to answer both questions in Chapter 3 in order to evaluate potentials and problems in the theory on democratic innovation, posing three criteria to evaluate success: the capacity to democratize state practices, the capacity to expand citizenship and the capacity to distribute public goods. It is my main point that participatory budgeting was successfully exported from Brazil such that all three of these elements were retained, as I will show when I discuss the experience in Rosário in Argentina. It is also my contention that important experiences such as in Buenos Aires and São Paulo were unsuccessful because they could not resist the political system's drive to incorporate democratic innovation in a 'politics-as-usual' scheme.

The second important innovation I will deal with in the book is participatory accountability. In Chapter 4 I will fully explain the concept, which I differentiate from social accountability (Peruzzotti 
and Smulovitz, 2006) because it has a clear participatory element and because it represents a non-electoral and participatory form of continuation of public policies. I include in the cases of participatory accountability, councils in Brazil and Mexico and comités de vigilancia in Bolivia. Brazil is an example of success in the areas of healthcare and social assistance due to a state policy that instituted separation between elected mayors and a control body. The case of Mexico is very important because it shows both the success of an independent control body and the later political disempowerment of this same body - the IFE. The IFE incorporated citizens' practices and implemented a citizenship policy of control of electoral fraud between 1996 and 2006 (Avritzer, 2002; Schedler, 2000, 2002). Yet the IFE is also a case in which success was transformed into co-optation. The IFE's history is of co-optation of citizens' control by political parties and the quota system.

Finally, Bolivia is a successful case of participatory accountability since the enactment of the Ley de Participación Popular. The law not only transferred 20 per cent of the total central government revenues to local communities but also allowed the creation of monitoring committees that greatly enhanced the local administrations' performance in the areas of healthcare and education. After 2010, many cases in Bolivia involved the disempowerment of these committees by the Movement for Socialism (Movimiento al Socialismo - MAS).

Thus, we have three cases of participatory accountability: Brazil, Mexico and Bolivia. The three cases show a variation in one key aspect - the relation of accountability to the political system. Only when accountability becomes a state policy involving citizens' control of policy will innovations in accountability work well. This control cannot be politically disempowered or administratively performed, as I will show in the approach to judicial innovation.

\section{JUDICIAL INNOVATION: BETWEEN THE EXPANSION OF RIGHT AND SELF-INTERESTED AUTONOMY BY CORPORATIONS}

The last case I will deal with in the book is judicial innovation. There is not enough literature that differentiates political innovation from administrative/judicial innovation. The main assumption in the literature is that innovation encompasses both dimensions - political 
and administrative. However, there are enough grounds to seek an analytical distinction. The issues that differentiate political from administrative innovation are the nature of the bureaucratic control over innovation and the top-down elements of the policy. In the political cases I described earlier, participatory budgeting, comités de vigilancia and the IFE are all based on the same assumption, namely, breaking hierarchical control of bureaucracy and the political system over policies and transforming them into horizontal and participatory deliberation and/or accountability.

When we move from political to administrative innovations, we do not see this change. Administrative control remains top-down in all forms of administrative innovation. In addition, when we deal with the legal/judicial system we may see an additional problem of the role of professional corporations (Bourdieu, 1986; Luhmann, 1982; Rosanvallon, 2015). Professional corporations cannot be considered equivalent to citizens in the way they handle policies for one single reason: they dispute power with other state agencies and actors. The issue of creating new rules in the legal system requires a different approach. It is from this perspective that it is difficult to retain the idea that administrative and legal innovations involve the processing of citizens' input. On the contrary, in most cases of administrative innovation, there is no democratic input. It is from this perspective that I will analyse the third case of innovation - the Ministério Público and the Supreme Courts in Brazil and Colombia.

The Ministério Público follows from a judicial/administrative innovation made by the Brazilian 1988 Constitution. According to the Constitution, the Ministério Público would be the institution in charge of defending various rights and the union assets against corruption, in addition to its prerogatives in criminal cases (Rojas, 2011). To pursue both aims the Ministério Público would have full administrative autonomy. Thus, two innovations were introduced at the same time in the creation of the Brazilian Ministerio Público: the idea of diffuse rights and the idea of organizational autonomy. The Ministério Público in that case is a legal and administrative innovation that tried for a long time to defend its role as a representative of civil society institutions with a similar democratic drive (Pinto, 2004), a claim accepted by many scholars and social actors in Brazil with a few exceptions (Arantes, 1999). The Brazilian Supreme Court is not an innovation per se but the constitutionalization of judicial review is. 
The Ministério Público's strengthening role in the Brazilian political scenario shows what is wrong with the conflation of administrative and political innovation. It is true that in its first years it created legitimacy through the defence of civil and social rights, such as the right to health services and the rights of minorities such as the Brazilian indigenous population (Avritzer and Marona, 2017). However, as the Ministério Público matured as a legal institution, it revealed the problems of conflating political and legal innovation by both establishing a professional corporation-specific agenda and circumventing issues linked to individual guarantees. In Chapter 5 of the book I will use Ministério Público and the political decisions of the Brazilian Supreme Court as an extreme case of lines that political innovation should not cross.

However, Brazil is not the only case of judicial innovation. I will also analyse in Chapter 5 a case that seems to me more successful than Brazil's, namely the Constitutional Court in Colombia. The Colombian case is different because innovation is more clearly centred on the expansion of rights. In addition to that, in the key moments of dispute between the executive and the Constitutional Court it reiterated its role of revising the written Constitution and not on rewriting the Constitution. My point in this regard is that we should always bear in mind in the evaluation of institutional innovation the capacity of new institutions to foster citizenship and deepen democracy, a capacity that the judicial system may not have in some cases. This capacity should be clearly differentiated from judicial institutions' challenge to the balance of power, which is where most of the Latin American cases of judicial innovation are heading.

The last issue approached in the book is the different possibilities in regard to the consequences of innovation. In regard to participation I will show how innovation unleashes democratic impulses that deepen democracy. This is clearly true for cases of participatory budgeting, councils, the IFE and comités de vigilancia. However, the literature follows a logic that claims that once these innovations are implemented, they can be reproduced. I challenge this logic in this work. According to this logic, participatory innovation should be understood as allowing democratic deepening in all cases. I will show in Chapters 3 and 4 that expansion and routinization of innovation unleash more complex and mediated processes. In some cases, innovations are reproduced but without the processes that deepen 
democracy and citizenship. In other cases, innovation is successful, but the political system contains it or thwarts its most important aspects. Yet, democratic dangers are not linked to democratic innovation, as I will argue in the book.

Other cases, such as the Ministério Público and the Supreme Court in Brazil, and the Colombian Constitutional Court that has played a more democratic role than the Brazilian example, are different. In these cases innovation is undesirable whenever it weakens the normative core of rules without which the rule of law cannot operate.

In this regard, two key issues will be analysed in the book. The first is the difficult position of the political system in relation to innovation. The political system should be understood as the aggregative and electoral force that has an ambiguous relationship with innovation. It may be the force that, in certain cases, brought in innovation, but most of the time it is the drive that blocks innovation, because, as I will show in the book, innovation stands in tension with the political system in at least two ways: in cases of bottom-up innovation it diminishes power-holders' decision-making capacity on budget issues; in cases of participatory accountability it diminishes government control on policy orientation. Thus, democratic innovation has an element of deepening citizens' control over policy and budgeting, which reduces the control of the political system over them. This is why the political system is ambiguous in relation to innovation.

The political system uses different strategies for blocking innovation. The first is ignoring innovation or deliberative ways of handling problems (Avritzer, 2002; Dryzek, 2013; Elstub et al., 2016). However, there is a second issue, not addressed by the literature, that plays a similar role: co-opting innovation. I will argue in Chapters 3 and 4 that co-opting innovation takes place after innovation succeeds. I will show how that strategy was used in Mexico after democratization and in Brazil after the Workers' Party (Partido dos Trabalhadores - PT) victory in the presidential elections of 2002. I will also show that it is in operation within the MAS in Bolivia. Thus, the other issue in regard to innovation is that even in cases where it breaks with the political system or pressures it to adapt to citizenship, there is still the possibility that new elements will be integrated into 'politics-as-usual' practices. In this case, democratic deepening fails.

The other concern of the book is the dangers linked to judicial innovation. Judicial innovation may carry out the strengthening of a specific kind of professional corporation, namely, lawyers in charge 
of specific state institutions, the public ministry and the courts. Again, Brazil and Colombia are different cases and one of the most important innovations in Colombia - the acción de tutela (writ of protection) - does not require a lawyer. In the Brazilian case, lawyers pursued the strategy of strengthening rights but they also chose to strengthen their own corporation or government branch throughout this process (Bourdieu, 1986). The danger of judicial innovation is that disputes within monopoly institutions will be carried out in the name of innovation or that challenges to the democratic order will be made in the name of innovation, as I will show in Chapter 5 of the book.

Thus, the aim of the book is to evaluate both democratic innovation and the different strategies used to strengthen or weaken innovations. To deepen democracy and strengthen innovation, it is essential for democratic theorists to have a realistic analysis of its positive and negative aspects. Up to now, democratic theorists have presented only the positive elements of democratic innovations. It is my position that a more thorough analysis is needed, one that can incorporate a more nuanced view that presents not only the positive aspects but also the limits and the distortions of democratic innovation. Such work, instead of making innovation weaker, could help it become a defining feature of old and new democracies. 
Leonardo Avritzer - 9781786436658

Downloaded from PubFactory at 04/26/2023 10:25:53AM 